\title{
STRATEGIES OF RUSSIAN NGOS TO ENGAGE IN SOCIAL POLICY IMPLEMENTATION
}

\begin{abstract}
Although the Russian regime considers civil society to be a threat to its authority, social NGOs are positively viewed by state institutions at all levels. Unlike human rights organisations and political activists, socially oriented third sector organisations are not typically criticised by the propaganda machine. On contrary, these NGOs currently play a crucial role in social policy implementation in Russia. By analysing the trajectories of state-third sector relations of 18 Saint-Petersburg-based non-governmental elderly care organisations, the article characterises three ways in which NGOs approach relationships with the state: NGOs which support state policy by being part of it, NGOs which supplement state policies in spheres the state fails to address appropriately, and NGOs which substitute for the state, in some cases exercising power over local state social services.
\end{abstract}

Keywords: NGO-isation, social policy, clientelism, elderly care, Russia

\section{INTRODUCTION}

The third sector contributes to governmental social policies worldwide [Cammett, McLean 2011:2]. In Russia, it had been the case in the first years after the collapse of the USSR after the old Soviet social protection system ceased to exist [Cook 2013; Cook, Vingradova 2006: 29, 30; Henderson 2002]. Unlike the early years

M.Sc.Pol., PhD researcher; e-mail: arturs.holavins@helsinki.fi; https://orcid.org/0000-0001-5169-2201 
of the post-Soviet period, the latest wave of institutionalisation of third sector participation in social policy has been a deliberate governmental action in line with the global trend of ceding governmental social policy implementation powers to non-governmental actors [Tarasenko 2015: 295; Hvid, Camp 2012; Hills 2011]. This shift in welfare provision is part of a wider process called "welfare mix", referring to the growing complexity of social service provision in terms of variety of actors and their responsibilities [Oosterlynck et al. 2013: 12; Powell, Barrientos 2004; Evers 1995].

Recent changes in Russian social policies have allowed non-governmental actors to engage as contractors in state social care provision [Tarasenko 2018]. Transformations include the adoption of the Federal Law 442 "On Social Service Providers", the Ministry of Labour and Social Development white paper "Concept on Policies toward Aged People", as well as several regional and federal pilot programmes on third age education (education for recent pensioners, usually under 65 to 70 years), geriatrics, "silver" volunteering and ageing-related disease prevention measures. Legal recognition of social NGOs is important for the social and economic development of Russian society. The transformation, however, has been a complicated process, involving periods of uncertainty and requireing operational routinisation [Pelling et al. 2015]. Not all NGOs can or want to adapt to the changes, which require greater public oversight and what is perceived as a mission drift. Their strategies for collaboration with the state were different before and vary after the changes too. Studying the nature of these strategies is the primary focus of this paper. Analysis explores the primary research question, what are the primary forms of state-NGO relations in Russia, in light of recent social policy transformations?

As rules of the game have changed and the volatile environment has prevailed, NGOs have found themselves in uncharted waters with new forms of engamgement with the state. The author studied 18 NGOs providing various services to aged people (understood here and below as anyone of pension age, which was 55 for women and 60 for men at the time of the fieldwork) in Saint Petersburg - a key hub for non-governmental social policy implementation innovations in Russia. As a result of the research, I have identified the three most common approaches used by Russian social NGOs to engage with the state in this current, unprecedented period of third sector recognition: formal dependence (supplementing state social policies, i.e. "next to the state"), informal dependence (part of state social policies, i.e. "with the state") and reverse dependence (substituting the weakest 
governmental social service providers to become the dominating party in the relationship, i.e. "instead of the state").

These three approaches partly align with Bejoy K. Thomas and his colleagues' "multiple identities" of the Kerala state NGOs [2010: 360]. However, the ability of Russian NGOs to exercise power over the state and the tendency avoid conflict with governmental institutions distinguish the Saint Petersburg case from the Indian example. Below, I present the case, including research design, place it within a theoretical framework, and discuss empirical findings linking theory with the practice of social NGOs based in Saint Petersburg.

\section{NON-GOVERNMENTAL ELDERLY CARE PROVIDERS IN SAINT PETERSBURG}

As the state creates social policies and frameworks for non-governmental elderly care provision, civil society has to consider the existing rules, norms and principles of social service provision [Geyer 2001]. Their organisational activities, including sustaining operations and the search for resources to advance their mission - depend on both the legal framework and the availability of state financial resources. It is the case for any NGO disregarding their actual level of engagement with the state, as a decision not to engage in relations with the state is still a result of reflections over such possibility. In the Russian context, social NGOs also must also consider how to avoid obstacles created by repressive legislation on civil society organisations, which restrict the activities of any organisation with a political agenda.

In practice, however, compliance with rules, norms and policies varies widely by organization. Clientele organisations - meaning NGOs involved in the patron-client relations with the state - build strong relationships with governmental stakeholders at the federal and regional levels, satisfied with serving as "transmission belts" (someone providing legitimisation to the state by simulating grassroot civic activism) for state policies [Henderson 2002]. These relationships relations, in most cases, are informal [Cook, Vinogradova 2006], meaning that parties involved do not use written agreements, contracts, or bureaucratic procedures (such as grant competitions) to formalize their interaction. Instead, word of mouth and interpersonal communication prevails. The state plays the role of a patron, while NGOs are clients, paying with loyalty, ideological support and implementation of governmental policies through their activities [Ljubownikow et al. 2013; Danilova 2007; Gibson 2001]. They do it so seamlessly that some might find it difficult to differentiate between authorities and NGOs. 
"Civic" NGOs, representatives of small but cohesive third sector community members, constitute one half ( 9 of 18) organisations studied. Of the 18 organizations studied, only one, a charitable foundation, avoids having fund transfers from the state. Others receive governmental support through competitive grant or engage in the work of Public Councils. These organisations rely largely on formal procedures and mostly avoid behind-the-scenes arrangements with public officials. Although partly dependent on governmental funding, "civic" NGOs do not merge with the state. Instead, they stand "next to authorities" [McGivvern et al. 2015; Scheba, Mustalahti 2015; Bromme, Tillema, 1995]. In the Russian case, this means obtaining the recognized status of "social service provider" or otherwise having "expert knowledge".

Finally, there is a third type of relationship, largely borrowing the playbook of volunteer movements. Social media-based initiative groups have become a force for substituting failing governmental social services and providing care "instead of the state". They do so despite lacking legal status, recognition by the state or other elderly care providers, and with minimal financial and material resources. I identified two organisations having such reverse dependence relations with the state.

Notably, there is not necessarily a direct connection between the type of relations between NGOs and state, whether formal or informal, and level of dependence on the state. As I show below, "civic" NGOs in search of grants may also become dependent on official state funds. In contrast, clientelist relations between state patron and NGOs in Russia may simply serve as an additional resource for organisations, rather than as a sign of powerlessness.

\section{RESEARCH DESIGN}

This study is a snapshot of the state-of-the-art in non-governmental care provision in Saint Petersburg immediately after the Federal Law 442 "On Social Service Provision" (further - FL 442) took effect in 2015. The act represented a significant shift in social care, introducing a new "social service provider" status for NGOs that establishes legal rights and practical instruments to provide social services as contractors to state service beneficiaries. FL 442 followed a series of previous legislative shifts impacting social policy provision in Russia. The 2010 Federal Law 40 amended the 1996 law on NGOs by introducing the concept of "socially-oriented NGOs". Around the same time, the Ministries of Labour and Healthcare collaborated with regional governments to launch several pilot programmes on 
computer literacy promotion among aged people, aged volunteer movement development and creation of a network of geriatric centres.

Saint Petersburg, the city where fieldwork was completed, is home to five million people, and is the cradle for a number of such pilot programmes. The city is also home to thousands of NGOs, ranging from small informal initiative groups to national and international foundations. Despite the grim depiction of Russian civil society's struggles against the regime in mass media, there are a number of examples of successful interest representation, social projecting and grass-root initiative taking [Kulmala, Tarasenko 2016]. As part of a dramatic shift in social policy provision framework, social NGOs have become crucial actors of social service provision. At the same time, state institutions remained focused on formalizing an ideological framework, defining social service standards and ensuring control quality of service provision.

Federal and regional governments facilitate NGO dependence on the state through multiple instruments, including grant competitions, procurement calls, and material and informational support. Such dependence - a reference point for understanding state-third sector relationships - is not unique to Russian civil society. For instance, Scandinavian and Continental European non-for-profit social service providers are well incorporated into state welfare/care regimes [Sobris 2013; Simonazzi 2008; Daly, Lewis 2003]. The particularity of the Russian case, however, is that the supposedly 'grass-roots' third sector has a long history of being overshadowed by the government. Since Soviet times, many NGOs have been hugely dependent on the state [Olompiev 2017; Cook 2007; Henderson 2003]. Mass movements and professional unions were part of a tightly controlled political sphere, serving as a mechanism to legitimize the regime. Despite formal independence, these organisations were instrumental to state politics and functioned under top-down control [Evans et al. 2006].

At the same time, unconscious adoption of prevailing ideological and organisational principles through socialisation - coercive isomorphism - may lead to changes in project priorities and behaviour, regardless of the type of organisation [Jarvis 2014]. This is possible in the case of Russia, as many "civic" NGOs participate in national grant competitions and receive subsidies from the state. Seventeen out of 18 elderly care NGOs studied receive some degree of state support.

Of all NGOs providing social services in Russia, I examined a specific subset of organizations providing a range of social services to retirement-age people. Overall, an estimated 150 NGOs provide social services to aged people in Saint Petersburg. The 18 NGOs selected for the study vary in size, operation budget, status, types of social services offered, degree of state-dependence and recognition 
by other third sector community members. The fieldwork covers Saint Petersburgbased social NGOs providing social services to aged people in the city itself and, in some instances, surrounding rural areas.

The primary empirical data used in this article were collected from semistructured interviews and participatory observations. Step-by-step involvement in key events of the third sector community, "snowball" tactics and overall good relations between organisations helped to establish access to the field through trustworthy and robust personal ties with many people involved in nongovernmental elderly care provision, including project managers, caregivers, or care recipients themselves. I conducted all observations and nearly all interviews. Some additional data was gathered via email and social media with the help of research participants and colleagues, which included useful links to reports, photos, draft documents and legislative changes to elderly care provision.

I conducted 48 semi-structured interviews with 50 research participants; each interview lasted between 30 and 150 minutes. The list of research participants included representatives from 18 NGOs ( 7 "expert" organizations, 4 self-help groups, 3 state-dependent clientelist associations, 3 volunteer groups and 2 Moscow-based grant-making organizations). Interview participants included 6 care receivers, 23 caregivers, and 29 care organisers. Notably, some research participants simultaneously fell into two categories. Most of the interviews were recorded and transcribed; some were documented in a fieldnote diary, which also was used to structure all participatory observations noted below. The main selection criterion for individual interview participants was their direct experience with care provision at their respective organisations. Therefore, employees having both organisational and caregiving responsibilities were of primary interest. The research participants consisted of 19 men and 31 women, with ages ranging from 19 (volunteer) to 88 (head of the veteran organisation). Majority of research participants had completed higher education, with the exception for two care receivers, as well as four younger caregivers who were still studying at college at the time of the interviews.

Descriptive and, to some extent, interpretative coding followed saturated description [Flick 2011: 152, 154; Miles, Huberman 1994: 54, 58]. Descriptive coding provided a detailed review of by-line topics, discourses and context, whereas interpretative codes helped to see some "hidden" meanings. At the same time, saturated description helped to put issues and discourses into sociological categories and constructions. In other words, descriptive coding provided structured data, while saturated description provided a meaningful interpretation of it. 


\section{INFORMAL RELATIONS}

It might appear that that patrons, i.e. state institutions, exercise power over their clients, which include numerous veteran organisations. In practice, both informal ties and more formal relationships demonstrate the complex dynamic of interdependence. Although informal relationships are not part of observations due to obvious field access limitations, , a mix of interviews and document analysis produced sufficient proxy data to piece together the nature of these relationships .

As stated above, in Saint Petersburg, most of financial resources and in-kind contributions for the operation of veterans' organisations comes from state institutions. This is the case for six of the seven veterans' organisations included in the study (which include both self-help support groups and "Potemkin", i.e. "façade" NGOs [Hemment 2012]. As funds are largely allocated based on interpersonal requests, veterans' organisations are among the most active NGOs to participate in informal relations with the state. This can be attributed to various reasons, with the Soviet legacy being one of them [Henderson 2003; Gibson 2001].

Up until this day, clienteles remain at the forefront of the ideological battle representing a loyal, state-supported civil society. In the offices of organisations selected for the study, I noticed photos from pro-governmental rallies and portraits of the President of the Russian Federation Vladimir Putin. All public and military holidays are marked by the organizations with "patriotic" rhetoric both in speeches by the leadership and posts in social media. When asked about the goals of the organisation, research participants representing veteran organisations mentioned "patriotic education of youth" and "ensuring pride for the state". The leadership of three veterans' organisations had professional military backgrounds. For these organizations, the background of their management has certainly contributed to crucial connections with influential regional stakeholders all the way up to the Governor and suggests shared conservative "statist" values.

In exchange for unequivocal support in the media, fake activism (e.g. inviting exclusively loyal members of local organisations to so-called "open organising public hearings") and support for state ideology, regional and local public officials and government agencies agree to be reliable donors. They also ensure that no other stakeholders support their clients:

"Only regional MPs can provide us with money" - Research participant \#22, Taisiya Yakovlevna (Female, in her eighties), chairperson of the Malinovo municipality local-level branch of the All-Russia organisation "Veterans"1.

All names are pseudonymised for the ethical reasons. 
As a result, veteran organizations act upon state initiative, providing material support in the form of in-kind contributions, including - gifts before holidays to older people. Other services such as excursions or concerts, also organised by the decision of the regional authorities. Altogether there are many forms of support to the clientelist NGOs, with funding and material goods being the most straightforward type of relationship. There is also informational support from patrons to their clients, as local newspapers cover activities of veteran organisations. In return, clientelist organisations such as all-Russia "Veterans" provide services to their patrons. For example, they may organise meetings with the electorate:

"Sometimes we meet with rayon administration officials. We bring hundreds of people. Public officials come" - Taisiya Yakovlevna, "Veterans" local branch leader (Female, in her eighties).

In other words, the organization builds a façade of civic activism and provides additional electoral dividends to local MPs. It also goes for most of 'calendar care', i.e. holiday celebrations involving aged people Nevertheless, if non-governmental organizations satisfy the needs of their governmental patrons, state institutions will not aim to control the whole spectrum of care services that these organizations offer to beneficiaries. In fact, all three veterans' self-help support groups studied avoid strict caregiving accountability associated with formal grant-giving competitions and tenders. None of these organisations seeks "social service provider" status or expertise recognition by the third sector community. Thus, they do not aim to "professionalise" [Krause 2014; Jalali 2013]. This leads to a certain degree of independence for "clienteles" from limitations established by FL 442.

Being entirely reliant on the state has apparent repercussions for the autonomy of veterans' NGOs. For instance, regional branch project managers from the All-Russia's veteran organisation "Theatre" are unsure about the non-governmental status of their organisation. In two interviews, representatives of this organisation mistakenly called it a "governmental" institution:

"Financing comes here from Moscow, as 'Theatre' is a governmental [institution]" - Research participant \#37, Mikhail Supov (Male, in his twenties), project manager and lecturer at all-Russia organisation "Theatre". (...)

'Why is computer literacy our main project? There was a decision made by the government, the President. Therefore, we run the project' - Research participant \#35 Pavel Sidorov (Male, in his thirties), project manager at all-Russia organisation "Theatre".

Mikhail and Pavel added that neither they nor their organisation has the power to decide what types of services to provide to aged people. For instance, if 
Ministries or the regional government decides that the elderly population should participate more in the labour market, "Theatre" will run programmes aimed at promoting economic activity of this population; this is true for any of the organization's shifts in care provision. Furthermore, the executive director justifies full dependence on the state and paybacks to patrons as a "normal" characteristic of vertical power relations within the state system:

"That is how work is done. There are central, regional, and local and communal branches. Vertical hierarchy has always been effective, since Spartan times (...) We cooperate with the city administration closely, and with the executive and legislative powers as no one else does (...) I can approach the governor, touch his shoulder and ask what I want (...) [We participate in all meetings, marches, gatherings to implement state policies] This is the mentality of the Russians to be always with their country, their state. This is our Russian particularity" - Research participant \#39, Ilya Bronislavovich (Male, in his seventieth), head of Saint Petersburg branch of all-Russia organisation "Theatre".

Here Ilya Bronislavovich recognises that his organization is highly incorporated into the state's vertical system of power. The interests "Theatre" represent are those of the state, and not "their own" [Shefner 2008]. Such patron-client relations are "involuntary and hierarchical" and have "defined timing" [Barsukova 2004: 27]. They also are "functional [as opposed to personal] and involve "administrative powers" [Barsukova 2004: 28].

On the other hand, some other veterans' organisations effectively employ dependence on the state for their own purposes [Kulmala, Tarasenko 2016]. Research participants from clientelist NGOs claim organisational agency in line with Batley [2011: 306], who states that "although structural factors have force, NGOs can re-interpret and even reverse structures of power". For example, Irina Tishko, cultural program coordinator at the clientelist "Interneters", dismissed a "marionette" role in the interview:

"We are partners of the state [not servants]. We cannot say we are merely a contractor organisation" - Research participant \#20, Irina Tishko (Female, in her twenties), cultural programme coordinator at all-Russia organisation "Interneters".

This is one of many examples of expressed pride for the organisation and declaration of its uniqueness and independence. Such organisational identity comes in conjunction with bureaucratisation and operation orientation. For clienteles, it is also a way to claim agency in relationships with state institutions [Thomas et al. 2010]. Self-help support groups are especially keen on using "continuation of formal institutions and practices" [Barsukova 2004: 28] for 
their own benefit. Each of the three veterans' organisations shared stories of using interpersonal relations to support their own agenda or of asking officials for additional financial support. As a result, a "coldness" and informality mitigate the "hierarchy" of patron-client relationships.

In conclusion, informal relations between clientelist NGOs and the Russian state produce a variety of dynamics. The FL 442 has had little impact on these dynamics, as none of the veterans' organisations seeks "social service provider" status or participates in medical/social care. Uncertainties around the law did not apply to veterans' organisations and did not change the nature of their relationship with the state. None of the research participants representing "clienteles" complained about the changing policy framework or even consider changes somehow meaningful to their daily work. The Russian policy framework transformation did not concern veterans' organisation, which play a niche role among social NGOs. The field research proved that, in some instances, Saint Petersburg elderly care providing clienteles serve a "transmission belt" role [Gibson 2001] in hierarchical relations with the state. Interviews also provided enough evidence to demonstrate that that grassroots veterans' organisations can use cut ties with the state to reclaim their own agenda [Kulmala and Tarasenko 2016] and accumulate additional resources through informal interpersonal relations [Batley 2011].

\section{FORMAL RELATIONS}

Formal relations, in the case of St. Petersburg NGOs, are relationships based on legally binding and formally defined forms of collaboration. These include national grant competitions, formal programme subsidies and other written and transparent connections. These relations are structurally formalistic and bureaucratically comprehensive. The formality of relationships is not necessarily a unique feature of state relations with professional NGOs. Relationships with clienteles can be formal too. The difference is that civic NGOs' state-funded activities are exclusively formal. There is little space for collaboration outside of written arrangements and legislation, and there are no "patron-client relations" involved [Cook, Vinogradova 2006].

The share of state funds in the budgets of Saint Petersburg's civic NGOs varies significantly. On the one side of the continuum, there are grant-makers. These receive no state contributions to their budgets at all. On the other hand, there are resource centres, like the aged volunteer promoting organisation "Snowflake", whose funds are largely from the state. As an active service provider of non-governmental elderly care provision, the organisation does not receive direct 
material support from state "patrons" and does not participate in gift distribution. Instead, the resource centre, like several other members of the third sector community, build formal grant-maker-grant recipient relationships with the state:

Interviewer: So, you would not say your organisation is dependent on the state, or that the state influences your activities?

Research participant \#4, Polina (Female, in her thirties), vice-president, project manager and lecturer at "Snowflake": "Well, we are a non-governmental organisation. We, in principle, do not depend on anyone. That is, we can live without finances, [if there is no money, we would] work voluntarily. Of course, we would like to have funds, so that we could bring people somewhere, do something, print materials. Moreover, therefore, we receive subsidies, grants. However, all of it we get in a fair way. That is if we apply, we win; we receive [funds], we are accountable for this money".

According to Polina, the formal rules of state grant competitions are "fair". They are not different from the competitions of private grant-makers. In other words, there is nothing unique about receiving financial support from the state. Additionally, she claims that NGOs are flexible enough to survive even without financing at all (implying financial support does not convert into dependence). This is not necessarily true, as "coercive isomorphism" - a process of adapting the values and aims of powerful grant-makers - might arise [Jarvis 2014; Verbruggen et al. 2011]. The phenomenon is not specific to dependence on governmental actors, but marks formalisation, bureaucratisation and operation orientation processes, i.e. NGO "professionalisation" [Jalali 2013].

In addition, civic NGOs receive recognition of their expertise by the state through formal recognition of a social status (i.e. "social service providers"), repeated allocation of grants, and engagement in public councils. Five out of seven professional NGOs studied receive financial support from the state through formal arrangements. The remaining two are not social service provision organisations, but grant-makers themselves. All of those five organisations participate in public councils. Three NGOs have been designated with the status of "social service providers". The other 2 in the group of seven are part of a transforming landscape of Russian caregiving policies too, as they participate in expert knowledge creation and dissemination by writing methodological materials, hosting professional conferences and actively participating in debates over a policy framework for the aged population of Russia.

Formal relations position NGOs as "standing next to the state". The Russian authorities recognise the role of social NGOs, and the FL442 provides a critical legal framework for that [Benevolenski, Toepler 2017]. Civic NGOs participating 
in the study noted a high degree of concern around uncertainty. They are also organizations which seek to adjust organisational procedures to comply with the newly established "social service provider" status. Several NGOs studied have joined "independent quality assurance audit commissions" - new institutions in social service provision aimed at involving non-governmental actors in external audits of social service provision.

\section{REVERSE DEPENDENCE}

Although rare, there are cases when state institutions must rely on the non-governmental sector. One of the most indicative cases is of the relationship between "Mermaid", an institution providing temporary elderly care , and activists from the movement " "Prometheus", which emerged from social networks.

Since 2010, "Prometheus" volunteers have been visiting elderly care facilities in the rural area outside of Saint Petersburg, including the above-mentioned "Mermaid", a branch of a large government social service institution. During their visits, volunteers talk to the elderly, hold their hands, listen to their stories, provide them with food, clothes and other material goods, bring medical and sanitary equipment to medical personnel of "Mermaid", stage plays and organise games.

As an institution, "Mermaid" is exceptionally well appointed and developed. Unlike many nursing homes in the rural region, the institution has a lawn, sauna and well-equipped facilities. Artistic installations, bookshelves, and curtains make it feel homey. It also has sufficient medical equipment and even runs its own bakery. While by all appearances doing well, the branch continuously lacks money and other resources and is largely neglected by agency leadership, who visit the facility once a year. There is a persistent lack of diapers and no money for renovations. The relative success of the organization in providing quality care and improving living conditions for elderly residents can be largely attributed to the personal devotion of the director. Volunteers explain that the director brings curtains from home, employs an enthusiastic teacher to organise handicraft classes, invite support from a Finnish charity, and raise money by selling handmade crafts from the elderly and pies to pay her staff additional wages.

The "Prometheus" activists also serve as a valuable resource for the director. They raise charitable funds and collect material goods (including food, clothes, medical equipment, blankets, diapers) from among their thousands of members. In addition, volunteers visit the facility in large groups (around 20-25 permanent activists) not only enough to organise cultural events but also to improve the infrastructure of nursing homes through renovations or donations of medical 
equipment). Unfortunately, the director faces a significant obstacle which puts both her job and the success of the institution at risk. Assistance by volunteers goes against complex formalist and bureaucratic inter-organisational relation requirements, which demands certificates, official agreements, and tender competition procedures. In effect, the leadership perceive volunteers as an unwanted political issue. They see non-governmental assistance in "fixing things" [Tronto 1993] as proof of the failure of government officials to ensure decent care for the elderly. As a result, local authorities fear volunteers.

Furthermore, "Mermaid" has no legal or any other instruments to force volunteers to do anything they do not want to do. While "Prometheus" volunteers listen to the director and consult her out of deep respect for her professionalism and personal qualities, other activists disregard her opinion often. For example, a one-time corporate volunteer group once painted the kitchen walls despite a plea to bring new chairs.

"Prometheus" volunteers are aware of both issues. Overall, they have an excellent long-term personal relationship with the director. Thus, activists always consult her on projects and priorities. Volunteers also readily provide their support out of sight to avoid all legal obstacles and potential backlash from authorities. Notwithstanding the stable and mutually-respectful relations, the governmental-run social service provider finds itself dependent on volunteers to get things done and run smoothly [Barber, Bowie 2008: 749]. The above-presented case shows inequalities in power relations, which cannot be explained merely by position in the social service system (where the state would be a decision-maker ruling over non-state actors of elderly care provision). It also demonstrates the dilemmas which state social service providers face in the interplay between their role in state hierarchies and their mission to deliver quality care.

\section{CONCLUSION}

The article contributes to a broader debate on the role of social NGOs in the transformation of the contemporary welfare state, its civil society capabilities, and roles and opportunities in state social policy-making processes as well as to discourse on what motivates NGOs to remain independent from the state or, conversely, remain heavily dependent on governmental institutions.

The case study of Saint Petersburg's non-governmental elderly care providers is not necessarily universally comparable to broader global contexts. Nonetheless, it presents a noteworthy example of the challenges and obstacles non-state actors face in their quest to achieve 'expert' status recognition from governmental 
institutions, compete for state financial and non-financial support, and generally secure a place in the rising "welfare mix" system [Evers 1995].

One specific characteristic of the Russian case is the authoritarian political regime which shapes its context. Unlike many other developed care and welfare state regimes, Russian social policies exist in the framework of a top-down, paternalistic state, with limited opportunities for grassroots initiatives and civic activities. Social NGOs, unlike their human rights peers, are generally viewed positively and do not face direct legal or political repercussions. Nonetheless, limits to ability of NGOs to participate in state decision-making processes and the need to comply with rigid state-defined principles of elderly care implementation reduce NGO's capacity to take initiative and diminishes their innovative potential to drive grassroots change in civil society and the care provision sector.

As a result, three significant strategies have emerged - "formal" and "informal" relations between NGOs and the state, as well as nurturing of "reverse dependence". The first strategy is used by NGOs willing to secure their independence. They collaborate with state institutions strictly within the limits of the legal framework, including a seminal Federal Law 442 "On Social Service Providers". Ideologically and in terms of self-identification, they "substitute" for the state in areas of their own expertise (e.g. elderly volunteering) by providing services unavailable or underdeveloped in state institutions. Civic NGOs are "third sector community members" and their ultimate goal is to build relations with the state as with any other donor [Alvarez 2009]. This strategy may resemble that of other non-state care regimes in democratic states.

The second strategy, "informal relations", is used by NGOs heavily structurally dependent on the state. By reproducing the Soviet legacy of imitating civil society for the sake of legitimizing the regime, these non-governmental elderly care providers have little interest in "civic" values. Instead, these NGOs - "clienteles" - navigate between being part of the governmental policies (often at the expense of their own third sector identity) and adapting to the political or personal interests of their state "patrons". In the latter case, NGOs engage readily in satisfying the needs of state institutions or individual state actors in exchange for access to the various resources through interpersonal connections. In some cases, this may lead the organization to become a 'de facto' state body. Sometimes these organizations manage to push their own agenda, making their relationships with the state a two-way form of interest representation [Kulmala 2016; Kulmala, Tarasenko 2016].

Finally, a third strategy, "reverse dependence", is demonstrated in the rare yet revealing case outlining the dependence of peripheral governmental social 
service providers on Saint Petersburg volunteer movements. This specific strategy outlines how diverse care regimes can exist within the same state. In other words, implementation of social policies is not only diverse across the state [Cammett, McLean 2014], or across contradicting ideologies pursued by different actors, but also across geographical, economic and social realities. In the Russian case, this diversity is characterized by the urban-rural division. Relatively poor urban activists have sufficient resources to make rural state institutions dependent on their assistance. A similar pattern is also expected to emerge in other states' this a matter for further research and comparative analysis.

Another crucial finding is that Russian NGOs engaged in social policy do not align with the strict dichotomy of state "transmission belts" [Gibson 2001] and civic opposition to the state [Cook, Vinogradova 2006]. All three types of NGOs engage with the state; only one out of eighteen organisations studied avoided interaction with the state altogether. Even the most active "civic NGOs" commonly had regular contact with state institutions. Clienteles, though highly dependent on informal governmental financial transfers and material support from the local government, have at least some degree of independence from the state. For their turn, "Grassroots" organizations, often seen to be on the outskirts of Russian civil society, occasionally exercise power over local state social service providers. Finally, changes in the social policy framework introduced by the Federal Law 442 "On Social Service Provision" had an impact only on the first strategy , namely, the "formal relations" strategy for the state-third sector engagement. Clientelist and reserve dependency strategies remain unchanged despite tectonic shifts in social policy implementation of recent years. Thus, there are still areas untouched by the new policy framework, and many social NGOs either ignore the new tools for resource distribution or are left to themselves by the state oversighting these tools. In other words, state control over civil society, as well as elderly care, is not absolute in the case of Russia.

\section{BIBLIOGRAPHY}

Alvarez Sonia E. 2009. "Beyond NGO-ization?: Reflections from Latin America". Development 52(2): $175-184$.

Barber Martin, Cameron Bowie. 2008. "How international NGOs could do less harm and more good". Development in Practice 18(6): 748-754.

Barsukova Svetlana Y. 2004. Nerynochnye obmeny mezhdu rossiyskimi domokhozyaystvami: Teoriya i praktika retsiproknosti. Moscow: HSE Press.

Batley Richard. 2011. "Structures and strategies in relationships between non-government service providers and governments". Public Administration and Development 31(4): 306-319. 
Benevolenski Vladimir B., Stefan Toepler. 2017. "Modernising social service delivery in Russia: Evolving government support for non-profit organisations". Development in Practice 27(1): 64-76.

Bromme Rainer, Harm Tillema. 1995. "Fusing experience and theory: The structure of professional knowledge". Learning and instruction 5(4): 261-67.

Cammett Melani, Lauren M. MacLean (eds.). 2014. The politics of non-state social welfare. Itaca: Cornell University Press.

Cook Linda J. 2007. "Negotiating welfare in postcommunist states". Comparative Politics 40(1), 41-62.

Cook Linda J., Vinogradova Elena V. 2006. NGOs Civic Society and Social Policy in Russia's Regions, Washington: The National Council for Eurasian and East European Research (Title VIII Program).

Daly Mary, Jane Lewis. 2000. "The concept of social care and the analysis of contemporary welfare states". The British Journal of Sociology 51(2): 281-298.

Danilova Natalya. 2010. "The development of an exclusive veterans' policy: The case of Russia". Armed Forces \& Society 36(5): 890-916.

Evans Alfred B., Laura A. Henry, Lisa McIntosh Sundstrom. 2006. Russian civil society: A critical assessment. London, New York: M.E. Sharpe.

Evers Adalbert. 1995. "Part of the welfare mix: The third sector as an intermediate area". Voluntas: International Journal of Voluntary and Nonprofit Organizations 6(2): 159-182.

Geyer Robert. 2001. "Can the European Union (EU) social NGOs co-operate to promote EU social policy?". Journal of Social Policy 30(3): 477-493.

Gibson James L. 2001. "Social networks, civil society, and the prospects for consolidating Russia's democratic transition". American Journal of Political Science, 51-68.

Henderson Sarah L. 2002. "Selling civil society: Western aid and the nongovernmental organization sector in Russia". Comparative Political Studies, 138-167.

Hemment Julie. 2012. "Nashi", youth voluntarism and Potemkin NGOs: Making sense of civil society in post-soviet Russia". Slavic Review 71(2): 234-260.

Hills John. 2011. "The changing architecture of the UK welfare state". Oxford Review of Economic Policy 27(4): 589-607.

Hvid Helge, Annette Kamp (eds.). 2012. Elderly care in transition: Management, meaning and identity at work: A Scandinavian perspective. Copenhagen: Copenhagen Business School Press.

Jalali Rita. 2013. "Financing empowerment? How foreign aid to Southern NGOs and social movements undermines grass-roots mobilisation". Sociology Compass 7(1): 55-73.

Jarvis Darryl S.L. 2014. "Policy transfer, neo-liberalism or coercive institutional isomorphism? Explaining the emergence of a regulatory regime for quality assurance in the Hong Kong higher education sector". Policy and Society 33(3): 237-252.

Krause Monika. 2014. The good project: Humanitarian relief NGOs and the fragmentation of reason. Chicago: Chicago University Press.

Kulmala Meri, Anna Tarasenko. 2016. "Interest representation and social policy making: Russian veterans' organisations as brokers between the state and society". Europe-Asia Studies 68(1): 138-163.

Kulmala Meri. 2016. "Post-soviet political: "Social" and" political" in the work of Russian socially oriented CSOs". Demokratizatsiya: The Journal of Post-Soviet Democratization 24(2): 199-224. 
Ljubownikow Sergej, Jo Crotty, Peter W. Rodgers. 2013. "The state and civil society in PostSoviet Russia: The development of a Russian-style civil society". Progress in Development Studies 13(2): 153-166.

Olompiev Konstantin S. 2017. "Vlastnye instituty i grazhdanskoe obshhestvo: Evoljucija vzaimootnoshenij v perehodnyj period otechestvennoj istorii (1985-1991 gody)" [State Institutions and civil society: Relationship evolution in transitional period of patriotic history in 1985-1991]. Ars Administrandi 9(1): 1-15.

Oosterlynck Stijn, Yuri Kazepov, Andreas Novy, Pieter Cools, Florian Wukovitsch, Tatiana Saruis, Eduardo Barberis, Bernhard Leubolt. 2013. Exploring the multi-level governance of welfare provision and social innovation: Welfare mix, welfare models and rescaling. Antwerp: Improve Working Papers.

Powell Martin, Armando Barrientos. 2004. "Welfare regimes and the welfare mix". European Journal of Political Research 43(1): 83-105.

Rosstat. 2016. Aged Population Demographics. Rosstat. http://www.gks.ru/wps/wcm/connect/ rosstat main/rosstat/ru/statistics/population/generation/\# [access: 10.03.2020].

Scheba Andreas, Irmeli Mustalahti. 2015. "Rethinking 'expert'knowledge in community forest management in Tanzania". Forest Policy and Economics 60: 7-18.

Shefner Jon. 2008. The illusion of civil society: Democratisation and community mobilisation in low income Mexico. University Park: Pennsylvania State University Press.

Simonazzi Annamaria. 2009. "Care regimes and national employment models". Cambridge Journal of Economics 33(2): 211-232.

Tarasenko Anna. 2015. "Russian welfare reform and social NGOs: Strategies for claim-making and service provision in the case of Saint Petersburg". East European Politics 31(3): 294-313.

Tarasenko Anna. 2018. "Russian non-profit organisations in service delivery: Neoliberal and statist social policy principles intertwined". Europe-Asia Studies 70(4): 514-530.

Thomas Bejoy K., Roldan Muradian, Gerard de Groot, Arie de Ruijter. 2010. "Confronting or complementing? A case study on NGO-state relations from Kerala, India". Voluntas: International Journal of Voluntary and Nonprofit Organizations 21(3): 358-370.

Tronto Joan. 1993. Moral boundaries: A political argument for an ethic of care. New York: Routledge.

Verbruggen Sandra, Johan Christiaens, Koen Milis. 2011. "Can resource dependence and coercive isomorphism explain nonprofit organizations' compliance with reporting standards?". Nonprofit and Voluntary Sector Quarterly 40(1): 5-32.

Arturs Holavins

\section{STRATEGIE ZAANGAŻOWANIA ROSYJSKICH ORGANIZACJI POZARZĄDOWYCH W PROCES WDRAŻANIA ROZWIĄZAŃ POLITYKI SPOLECZNEJ}

\section{Streszczenie}

Chociaż władze rosyjskie uważają społeczeństwo obywatelskie za zagrożenie dla ich rządów, to społeczne organizacje pozarządowe (NGO) są oceniane pozytywnie przez instytucje państwowe na wszystkich poziomach władzy. W przeciwieństwie do organizacji broniących praw człowieka 
czy też aktywistów politycznych społecznie ukierunkowane organizacje trzeciego sektora raczej nie są krytykowane przez maszynę propagandowa, lecz wypełniają obecnie kluczową rolę we wdrażaniu polityki społecznej w Rosji. Analizując trajektorie relacji z władzą 18 organizacji pozarządowych z Petersburga, zajmujących się opieką nad osobami starszymi, artykuł omawia trzy typy relacji między NGO a instytucjami państwa: NGO wspierające politykę państwa poprzez bycie częścią tej polityki; NGO uzupełniające polityki państwa w obszarach, gdzie państwo nie potrafi odpowiednio rozwiązać problemów; oraz NGO zastępujące państwo, a w niektórych przypadkach sprawujące władzę nad lokalnymi państwowymi instytucjami społecznymi.

Słowa kluczowe: „NGO-izacja” (NGO-isation), polityka społeczna, klientelizm, opieka nad osobami starszymi, Rosja 